Volume 5, Issue 2 (Summer 2013)

\title{
Abraham Meeting the Lord and Two Angels: Making the Case for Ferdinand Bol and Workshop
}

Jan L. Leja

Recommended Citation:

Jan L. Leja, "Abraham Meeting the Lord and Two Angels: Making the Case for Ferdinand Bol and Workshop" JHNA 5:2 (Summer 2013), DOI:10.5092/jhna.2013.5.2.13

Available at https://jhna.org/articles/abraham-meeting-the-lord-and-two-angels-making-caseferdinand-bol-workshop/

Published by Historians of Netherlandish Art: https://hnanews.org/

Republication Guidelines: https://jhna.org/republication-guidelines/

Notes: This PDF is provided for reference purposes only and may not contain all the functionality or features of the original, online publication. This is a revised PDF that may contain different page numbers from the previous version. Use electronic searching to locate passages. This PDF provides paragraph numbers as well as page numbers for citation purposes.

ISSN: 1949-9833 


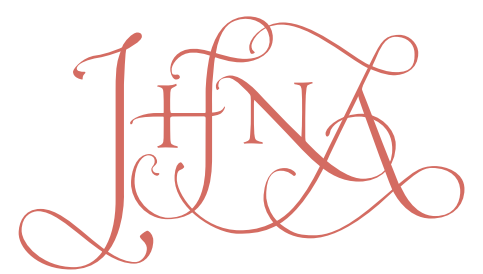

\title{
ABRAHAM MEETING THE LORD AND TWO ANGELS: MAKING THE CASE FOR FERDINAND BOL AND WORKSHOP
}

\author{
Jan L. Leja
}

Ferdinand Bol (1618-1680) is credited with the authorship of two drawings of the same subject, Abraham Meeting the Angels. One is a quickly drawn sketch and the other is a detailed drawing. The former is housed in the Rijksprentenkabinet, Amsterdam, the latter, in the Graphsiche Sammlung Albertina, Vienna. This article examines two aspects of these works, subject and authorship. In the course of the twentieth century, the subject was identified as both God Appearing to Abraham and Abraham Greeting the Angels. Here the arguments in favor of a more accurate title, Abraham Meeting the Lord and Two Angels, are examined. The authorship of the drawings is examined in terms of style, manner of execution, and iconographic innovation. The evidence that emerges supports the existing attribution of the Rijkprentenkabinet's drawing to Bol but argues for the attribution of the Albertina drawing to a Bol pupil. 10.5092/jhna.2013.5.2.13

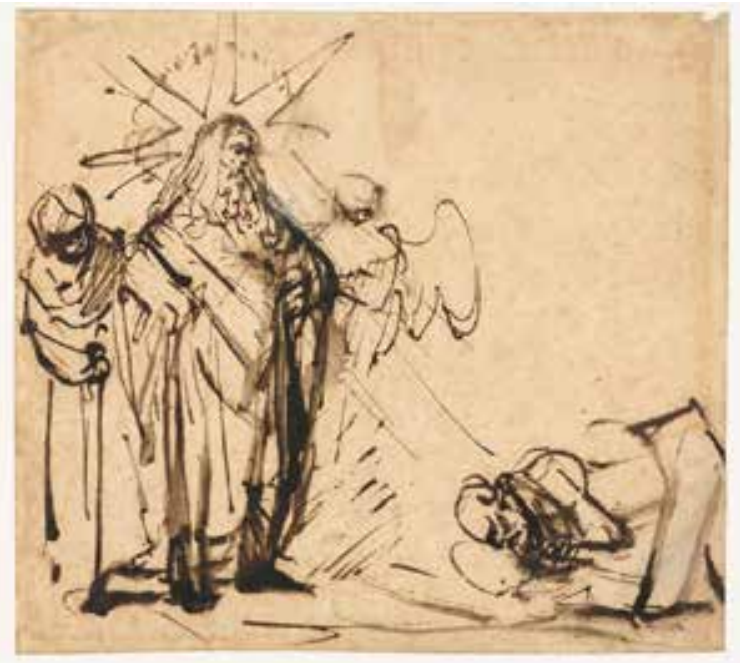

Fig. 1 Ferdinand Bol, Abraham Meeting the Lord and Two Angels, 1646 or later, pen and brown ink, white body color, $14.5 \times 15.9 \mathrm{~cm}$. Rijksmuseum, Rijksprentenkabinet, Amsterdam, inv. no. RP-T-19301 (artwork in the public domain)

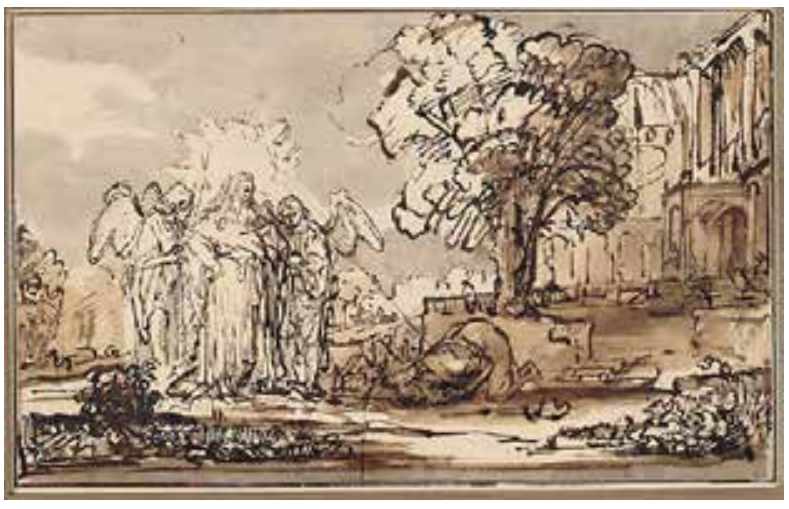

Fig. 2 Ferdinand Bol (workshop/follower), Abraham Meeting the Lord and Two Angels, after 1646, pen and brown ink, brown and gray wash, $17.6 \mathrm{x}$ $20.3 \mathrm{~cm}$. Graphische Sammlung Albertina, Vienna, inv. no. 8764 (artwork in the public domain)

The work of distinguishing Rembrandt's drawings from those of his pupils has occupied and preoccupied curators, art historians, and informed connoisseurs for decades. Among the numerous sheets attributed to any given Rembrandt pupil, it is rare that one can identify 
a relationship between two drawings that argues for the identification of one sheet as the work of the master, such as Ferdinand Bol (1618-1680), and the model used by an anonymous pupil or follower to create the other sheet. This article examines two drawings that represent Abraham Meeting the Lord and Two Angels (Genesis 18:1-2). One is housed in the Rijksprentenkabinet in Amsterdam (fig. 1) and the other in the Graphische Sammlung Albertina in Vienna (fig. 2). Today both are considered the work of Bol. The former is attributed to him on the strength of stylistic similarities it shares with two drawings, Study for Two Marys (Ossolineum, Lubomirski Collection, Wrocław) of ca.1644 and God's Messenger Appears to Joshua (private collection, United States) of ca. 1660-63, both of which are preparatory drawings for paintings. ${ }^{1}$ They establish a range for the dating of the Amsterdam drawing from the mid-1640s to the mid-1660s. The attribution of the Albertina sheet, however, is less secure because differences in style, execution, and function separate it from the Rijksmuseum drawing. These differences lead one to conclude that the Albertina sheet is the work of a Bol pupil or follower. Here I present the evidence that supports this conclusion.

\section{Toward Understanding Bol's Work as Draftsman}

The opportunity to examine a drawing by Bol in juxtaposition to a related work by an artist influenced by him rarely occurs. The scarcity of such comparisons has two principal explanations: one, our understanding of Bol's draftsmanship is incomplete, and two, our knowledge of the nature and quality of his pupils' work is limited.

In 1979 the first volume of Werner Sumowski's Drawings of the Rembrandt School appeared. It has remained a useful guide, despite its weaknesses, and is still the starting point for the study of Bol's drawings. Since 1979 two studies have appeared that clarify specific aspects of Bol's drawn oeuvre. The first, written by Ingrid Oud and published in 1992, examined the relationship between style and function in specific drawings Bol executed for prints and paintings. ${ }^{2}$ The second, written by this author and completed in 2004, established the nature of Bol's production while an assistant in Rembrandt's workshop and analyzed, in terms of authorship and iconographic innovation, drawings of biblical subjects that date to the first decade of his career as an independent artist, from ca. 1641 to $1650 .^{3}$ The latter group is the most important subset of drawings executed during that period because they provide the opportunity to study the stylistic diversity that marked his work, raise questions of authenticity, and offer evidence of Rembrandt's influence on Bol's draftsmanship. A comprehensive study of Bol's drawings, however, remains to be written and until such a study appears our understanding of Bol as a draftsman remains incomplete.

In the absence of a catalogue raisonné, curators and art historians have attempted to clarify Bol's work in an incremental manner. Since 2000, collection and exhibition catalogues have appeared that attempt to define Bol's work. Relevant titles among these publications are the exhibition catalogues published by the Berlin Kupferstichkabinett in 2006 and the J. Paul Getty Musuem in 2009, as well as the catalogue of the Lugt Collection and the online catalogue of the British Museum, both of which have been available since 2010, and the Hamburger Kunsthalle catalogue, which was published in 2011. ${ }^{4}$ These catalogues are useful tools for defining Bol's oeuvre, but they have limitations that arise from each author's unique understanding of the artist's draftsmanship. The limitations can best be explained by way of example. Bol's Annunciation (fig. 3) appeared in the Getty Museum exhibition, while his Angel Appearing to Hagar in the Desert (fig. 4) and Christ on 
Gethsemane (fig. 5) were published in the Lugt and British Museum catalogues, respectively. ${ }^{5}$ One need only glance at these drawings, all dated from ca. 1636 to ca. 1645, to understand how varied the penwork is. This raises the question: Can they all be by the same hand? These three works underscore the need for a comprehensive study of the artist's drawings.

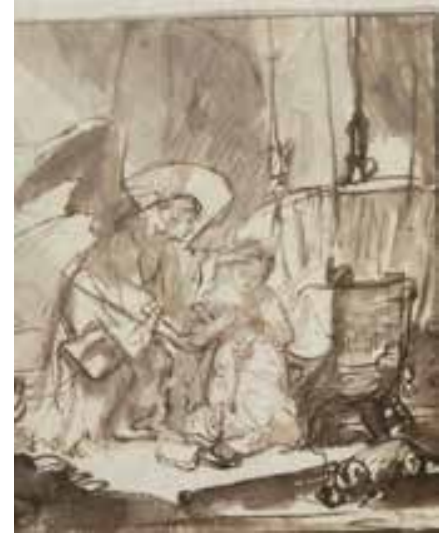

Fig. 3 Ferdinand Bol, Annunciation, ca. 1636-40, pen and brown ink, brush and brown wash, 19.4 x $16.5 \mathrm{~cm}$. Nasjonalmuseet for kunst, arkitektur og design, Oslo, inv. no. NG.K\&H.B.15591 (artwork in the public domain)

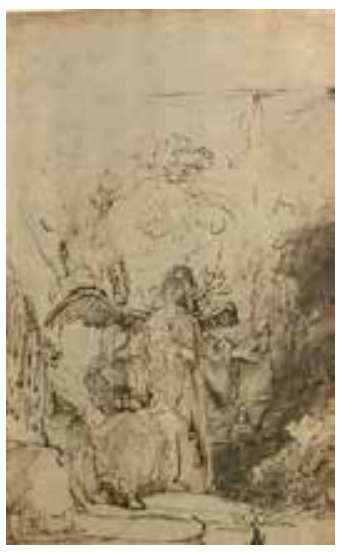

Fig. 4 Ferdinand Bol, The Angel Appearing to Hagar in the Desert, ca. 1636-40, pen and brown and gray ink, gray wash, 29.3 $x 18.5 \mathrm{~cm}$. Lugt Collection, Paris, inv. no. 2529 (artwork in the public domain)

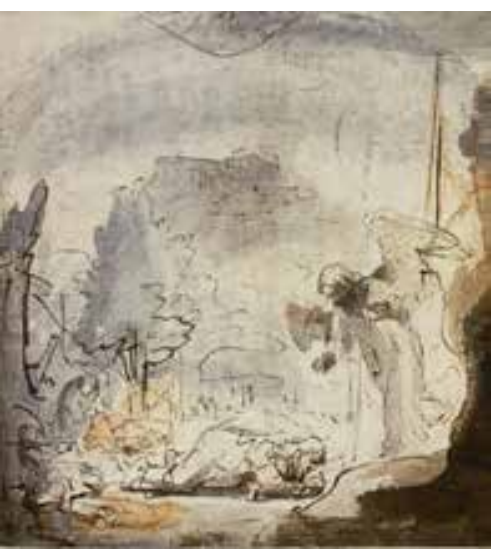

Fig.5 Ferdinand Bol, Agony in the Garden, ca. 1645 , pen and brown ink, touched with red chalk, brown, gray, and yellow wash. The British Museum, London, inv. no. 1918,0615.9 (artwork in the public domain)

Our knowledge of Bol's pupils and their work is highly fragmentary. Only four of Bol's pupils are known by name: Gerrit Willemsz Horst (ca. 1612-1652), Gottfried Kneller (1646-1723), Cornelis Bisschop (1630-1674), and Frans van Ommeren (active early 1660s). Horst is also known to have been a draftsman, but his output is tentative and limited. ${ }^{6}$ It is unlikely that a significant number of pupils, named or unnamed, will be identified to enable us to develop a broad understanding of their work. These considerable impediments to identifying the work of Bol's pupils make the findings of a case study such as this essay, where a clear relationship unites the work of master and pupil or follower, useful.

\section{Scenes from the Life of Abraham: Identifying the Subject of the Amsterdam and Vienna Drawings}

6 Throughout most of the twentieth century, the two drawings under discussion here were known as God Appearing to Abraham, the scene that is described in the opening verses of chapter 17 of the book of Genesis. ${ }^{7}$ In that scene, in which God announces to Abraham that he will produce a long line of descendents, Abraham is described as "bowing with his face to the ground" as he is depicted in both drawings. ${ }^{8}$ God, however, is usually depicted alone in a cloud being held aloft by putti. In these drawings the earth-bound representation of God makes it clear that the scene is not God Appearing to Abraham. The drawings, in fact, represent a scene from chapter 18 of Genesis, where three figures are met by Abraham, who is again described as "bowing with his face to the ground," as they walk across the plains of Mamre. ${ }^{9}$ This scene is known as Abraham Meeting the Angels.

Here I propose a more specific title for the drawings, Abraham Meeting the Lord and Two Angels, 
because it highlights the way the Lord and his companions were represented. The title has been borrowed from that applied by Michiel Roscam Abbing to Rembrandt's etching of 1656 (B. 26), Abraham Serving the Lord and Two Angels, and, by extension, to his well-known painting of 1646 of the same subject (fig. 6). ${ }^{10}$ In the painting, the Lord displays a decidedly greater physical and spiritual presence, the latter conveyed by an interior glow, than his companions. Rembrandt's work marked a new development in the treatment of the subject because it departed from earlier representations in which all three figures were portrayed either as men or as angels of equal size and importance. Roscam Abbing pointed to a marginal note that appeared in the 1637 edition of the Statenbijbel, where the three figures were described as two angels and the Lord, as one probable source for the change in Rembrandt's work. ${ }^{11}$

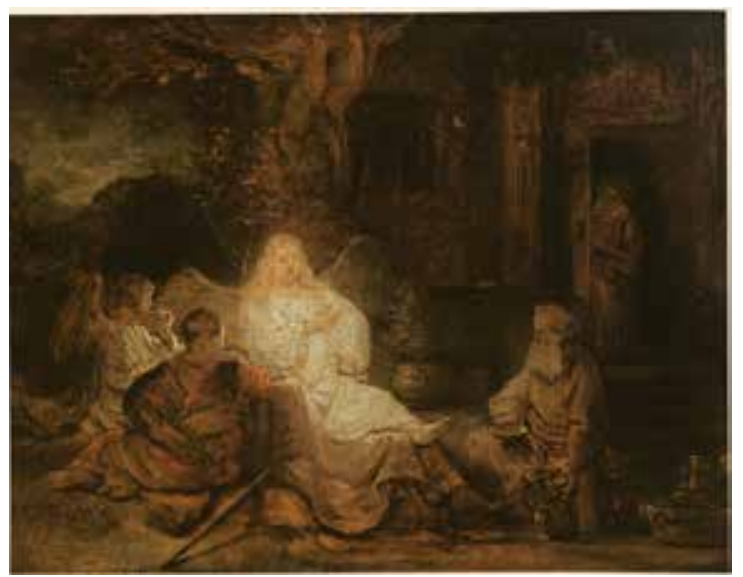

Fig. 6 Rembrandt, Abraham Entertaining the Three Angels, 1646, oil on panel, $16.1 \times 21.1 \mathrm{~cm}$. Private collection (artwork in the public domain)

Bol, in the Amsterdam drawing, followed the new direction established by Rembrandt by depicting the Lord as a towering, albeit wingless, figure whose divine character is symbolized by the rays of light that surround his head. The drawing may be dated to 1646 or later based on its relationship with Rembrandt's painting. It is also worth noting, even if as a digression, that Bol's paintings of the subject, here illustrated as figures 8 and 9, like the drawing, reflect Rembrandt's new approach to the representation of the angels: Bol made one of the three larger than the others, dressed him in white robes, and adorned him with white or light-colored wings that clearly set him apart from the other two.

\section{Iconographic Considerations: Recasting Abraham}

9 Rembrandt, as noted above, altered the identity of the angels in his painting of 1646 and etching of 1656 by identifying one of them as the Lord. The outdoor setting in which Abraham encountered the figures and where he later served them a meal, however, remained unchanged. It was defined, as already noted, by two vital components, Abraham's house and a large tree, the existence of which were recorded in Genesis.

10 Genesis 18:1 states that Abraham met the angels in the heat of the day and invited them to rest under a tree, the same place where he would later serve them a meal of curds, milk, and calf and where, more importantly, the Lord would deliver the news that Sarah would bear a son. The tree thus marked the spot where the annunciation of Isaac's birth took place and in placing it near the 
house, the draftsman remained faithful to the iconographic formula that defined the scene.

11 The house, in turn, marked the spot where Sarah heard the news that she would have a child, and artists, both those whose work influenced Rembrandt's and those whose work was influenced by him, remained true to the letter and spirit of the biblical text. They depicted Sarah partially hidden behind the door of the house just as she is described in Genesis 18:10-12. In 1616 Pieter Lastman (1583-1632) painted her partially concealed by the door of a modest, wooden house in Abraham Entertaining the Angels (fig. 7). ${ }^{12}$ Exactly thirty years later Rembrandt, following the Lastman prototype, represented her, again partly hidden, behind the door of a small, unadorned house. Lastman and Rembrandt used the house to convey a sense of the modest life led by Abraham and Sarah. Evidence of Bol's acceptance of the Lastman/Rembrandt model is found in two paintings of this subject: the first, a work of ca. 1650 (fig. 8), and the second, a work of ca. 1660-63 (fig. 9). ${ }^{13}$ Bol, like his precursors, placed Sarah behind the partially open door of a small house. In the later of these two paintings, Bol reduced the house to one of even more modest size than that which appears in the Lastman/Rembrandt prototype.

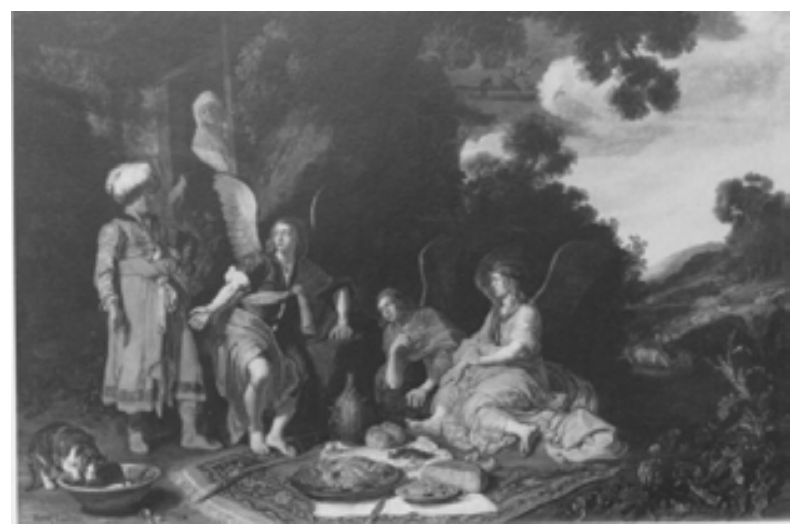

Fig. 7 Pieter Lastman, Abraham Entertaining the Angels, 1616, oil on panel, 82 x $126 \mathrm{~cm}$. On loan to Schloss Wilhelmshöhe, Kassel (artwork in the public domain)

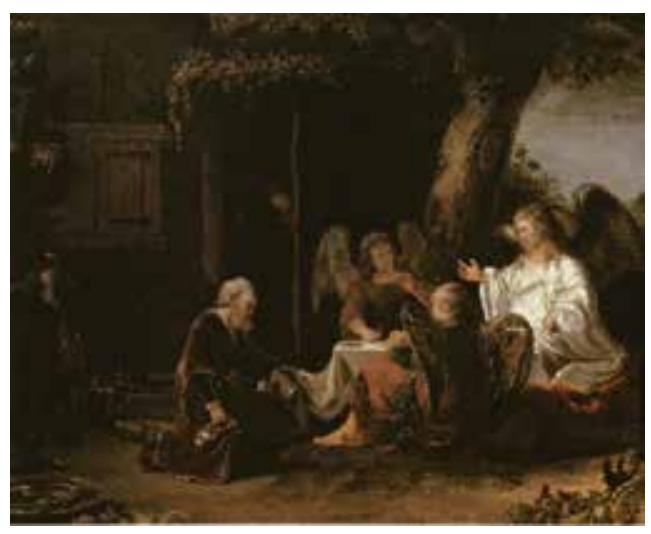

Fig. 8 Ferdinand Bol (or workshop), Abraham Entertaining the Three Angels, ca. 1650 , oil on canvas, $55.9 \times 73.3 \mathrm{~cm}$. Private collection (artwork in the public domain)

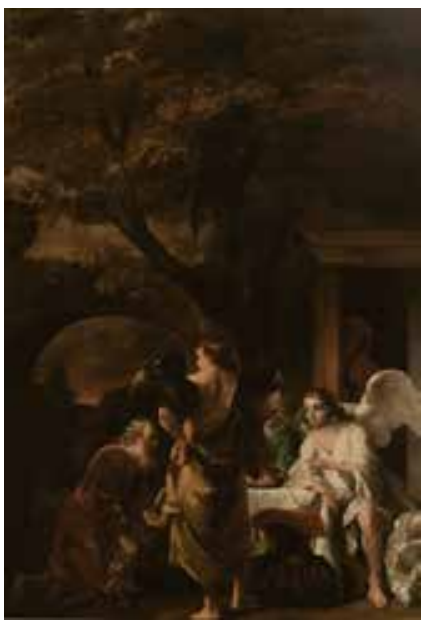

Fig. 9 Ferdinand Bol, Abraham Entertaining the Three Angels, ca. 1660-63, oil on canvas, 404 x $282.5 \mathrm{~cm}$. Rijksmuseum, gift of the Royaards Family, on loan to Noordbrabants Museum, 's-Hertogenbosch, (artwork in the public domain)

12 The draftsman of the Albertina sheet departed from this model when he transformed Abraham's small house into a much larger one. It is a fine multistoried structure with a colonnade adorning the ground level and a large porch leading to the main entrance. It is, in fact, so large that it can- 
not be overlooked, and a measure of its size is provided by Sarah, the tiny, almost imperceptible figure seen standing at the edge of the porch, who is dwarfed by the house. This transformation may appear to be an insignificant development for it does not change the outcome of the narrative. It had, however, broad implications because it recast the figure of Abraham: he was no longer the aged man who lived modestly with his wife in a small house; he had become a person of some means. This divergence from the characterization of Abraham found in Bol's work is significant for two reasons: first, because it argues for the authorship of another hand, one of his pupils or followers, and second, because it exhibits a willingness on the part of the Albertina draftsman to modify accepted iconographic conventions in a way that is rarely found in Bol's own work. ${ }^{14}$

\section{Amsterdam and Vienna: One Draftsman or Two?}

13 The figures of the Lord and Abraham, cast in similar poses and drawn with long, decisive pen strokes, leave no doubt that the drawings are related to one another despite the fact that the Amsterdam drawing was quickly executed, while the Vienna drawing was carefully produced. In both of them, the Lord's commanding presence is defined by his authoritative pose, as well as the rays of light surrounding his head, and Abraham's unfailing obedience is conveyed by the depth of his bow. The sheets are also united by the sparing use of line to create one of the smallest details they share, a walking stick. In the Amsterdam drawing, a single (nearly) vertical stroke of the pen created the stick held by the angel standing on the Lord's right. It identifies the trio as travelers on foot and allows the informed viewer to recognize the subject as the moment when Abraham greeted them as they approached his house.

14 Representations such as the Rijksmuseum sheet in which the angels and Abraham are depicted alone without narrative context provided by the presence of his house and a large oak were fairly uncommon. Lucas van Leyden was one of few artists who represented only the four figures. In Abraham Meeting the Three Angels (fig. 10), an engraving of ca. 1513, Lucas depicted Abraham kneeling before three standing figures, and he, like Bol later, placed a walking stick in the hand of one of the angels to identify them as travelers. In the print the upper portion of the stick held by the angel on the right is obscured by Abraham's arms, but the lower part is visible as it rests on the hem of Abraham's garment.

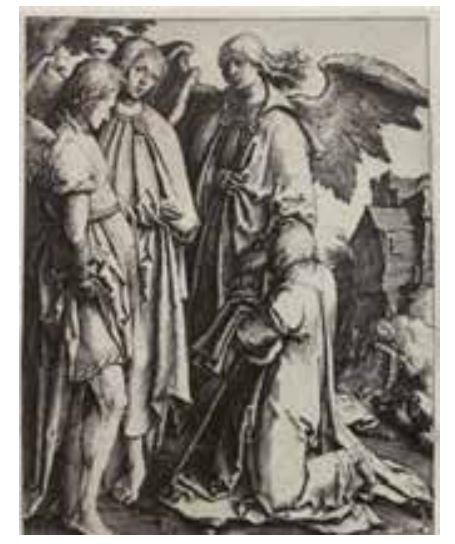

Fig. 10 Lucas van Leyden, Abraham and the Three Angels, ca. 1513, engraving, $17.8 \times 13.8 \mathrm{~cm}$. Rhode Island School of Design Museum, Gift of Murray S. Danforth, Jr., Providence, inv. no. 50.326 (artwork in the public domain)

In the Albertina sheet the walking stick held by the angel on the Lord's left is made not from a single stroke as it is in the Rijksmuseum drawing, but from two carefully drawn parallel lines. 
The angel steadies himself with the stick by positioning his hands on the top of it, one hand on the other. The stick's importance to the narrative is underscored by its presence in a work, like the Vienna sheet, where other narrative elements are present that also identify the scene.

16 The parallels that unite these sheets - the poses of the Lord and Abraham and the manner in which they were drawn as well as the inclusion of a simply drawn, but important, detail like the walking stick-lead to the conclusion that the works are different versions by the same artist. Indeed, this was the conclusion reached in 1979 by Sumowski, who favored the idea that the Albertina drawing was an "elaborate version" of the Amsterdam sketch. ${ }^{15}$ Differences in style, execution, and function, however, arise from closer examination of these drawings, and they argue for different authors.

\section{Style, Execution, Function}

17 The clearest differences in style are exhibited in the angels. Bol had a decided interest in themes in which angels were central figures, making it relatively easy to arrive at a general understanding of how he conceived of them. He painted, etched, and drew them throughout his career, beginning with his first dated painting of 1641, Gideon's Sacrifice (Rijksmuseum het Catharijneconvent, Utrecht) followed by three paintings of the same decade -- Three Marys at the Tomb (Statens Museum for Kunst, Copenhagen, dated 1644), Hagar in the Desert (Muzeum Pomorskie, Gdánsk), and Jacob's Dream (Gemäldegalerie, Dresden) -- and ending with one of his most important late paintings, a work discussed above (see fig. 9), Abraham Entertaining the Angels of ca. 1660-63.

18 Angels appear in at least four drawings that can be securely attributed to Bol in addition to the Rijksmuseum sheet. ${ }^{16}$ None of the winged figures found in these works compares favorably with their counterparts in the Vienna sheet even when one accounts for differences in function. Among the four, Bol's well-known Hagar at the Well on the Way to Shur (fig. 11) serves as an instructive comparative work in this context because it, like the Vienna sheet, is an independent work of art. The comparison provides evidence of easily observed differences that distinguish Bol's hand from that of the Albertina draftsman. The head, hair, and face of Hagar's angel are finely drawn. Bol created the impression of individual strands of hair on his forehead and of long tresses flowing to his shoulders. He also drew the eyes, nose, mouth, and even eyebrows with fine lines. By contrast, these features of the Albertina angel (fig. 12) were drawn with broad lines, allowing for no differentiation in the figure's hair and little refinement in his facial features. Bol also drew the position of the arms and the extended right hand in a manner that enabled him to indicate the flow of drapery over them. These details are more broadly drawn in the Albertina figure. The differences that distinguish these figures from one another argue against the attribution of the Albertina sheet to Bol. They support its attribution to an artist who knew his work, a pupil or follower.

19 Differences in execution also separate these drawings. The quickly drawn strokes that define the figure of the Lord in the Amsterdam drawing exhibit a change in execution. Bol altered the way drapery covered the figure's left arm, creating a pentimento. The pentimento can be best understood by examining the figure's pose. Bol drew him first with his hands akimbo. This can be easily observed on the figure's right side where his robes fall behind his elbow, allowing a clear view of the hand that is planted squarely on his hip. Bol attempted to do the same on the left side, 


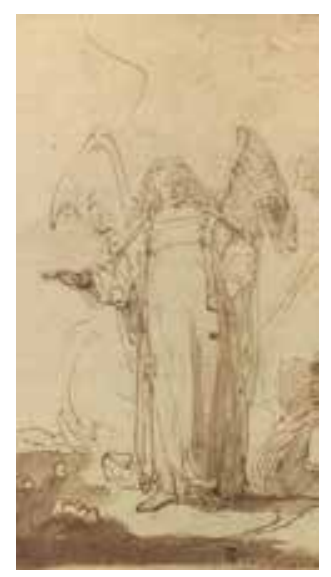

Fig. 11 Detail of Ferdinand Bol, Hagar at the Well on the Way to Shur, early-to-mid 1640s, pen and brown ink, brown wash, $18.2 \times 23.2 \mathrm{~cm}$. Rijksmuseum, Rijksprentenkabinet, Amsterdam, inv. no. RP-T-1930-27 (artwork in the public domain)

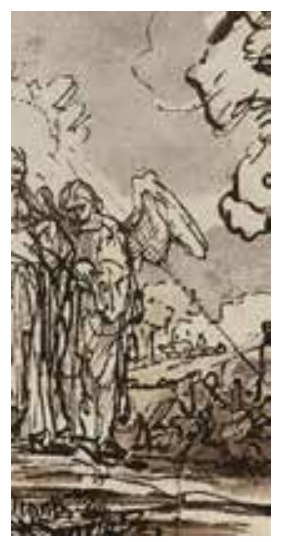

Fig. 12 Detail of fig. 2

where one can discern, despite the broad, vertical pen lines, a hand on the hip. The artist, however, changed his mind. He abandoned the idea of posing the figure with both hands on his hips and altered the drapery to fall over the elbow, thus obscuring his left hand. The dark brown pen lines represent the new position of the drapery. This change, a kind not uncommonly seen in a quickly sketched figure such as this, also appears in the Albertina sheet. Its presence there, however, argues against Bol's authorship, since one may assume that he would not have included this problematic passage in drawing the figure of the Lord a second time. The pentimento, then, helps identify the drawing as the work of an anonymous artist who knew the Amsterdam sheet and copied the figure of the Lord directly from his master's work, including this unresolved passage.

20 The Albertina sheet includes a detailed, painterly landscape. The artist produced it by creating a balance between the figures and the setting, establishing the illusion of recession leading into the middle distance and background, and using brown and gray washes to add tone to the vegetation and sky, respectively. The careful, conspicuous, and nearly uniform application of gray wash, in a manner that approximates paint, underscores the artist's intention of creating a convincing landscape. The wash imbues the sky with a gray tone and creates a solid background against which the Lord's commanding presence is heightened.

21 It is unlikely that this detailed landscape is the work of Bol because he was not a landscape draftsman. In his drawings, as in his paintings, he employed landscape primarily as a setting for figures and rarely drew it in detail. Bol executed the landscape elements in drawings of this type, like David Showing Saul the Tip of His Coat (fig. 13) and Jacob and Rachel (Harvard University, Fogg Art Museum, The Maida and George Abrams Collection, Cambridge), in a fairly quick, unstudied manner ${ }^{17}$ The painterly quality of the Albertina drawing, like the issues of style and execution raised above, places it outside Bol's oeuvre.

\section{Conclusion}

22 Among the many drawings securely attributed to Rembrandt's pupils, one can rarely trace the impact of a master on a pupil or follower. The two closely related drawings examined here are 
an exception for they display common characteristics of style and execution that allow one to evaluate the extent to which the Albertina draftsman used the Rijksmuseum drawing as a model. This examination also provides unexpected insights about the nature and pace of iconographic change. One generally thinks of iconographic change as a slowly unfolding process. These drawings demonstrate, however, that change could be fluid, occurring from one generation to the next not only between well-established artists, like Rembrandt and a named pupil, but also between a known artist and an unknown one, like Bol and an anonymous pupil. The evidence presented here suggests that, within the short space of roughly three decades, beginning in 1646 and ending late in Bol's life, the treatment of the subject of Abraham Meeting the Angels changed twice: the first time when Rembrandt represented one of the three visitors as the Lord, a change that Bol incorporated in the Amsterdam drawing; and the second time, after 1646, when Bol's pupil or follower altered the characterization of Abraham by transforming his small house into a much larger dwelling. Such an anonymous artist, like the author of the Albertina drawing, may be considered a second-generation Rembrandt pupil and, as such, he is a member of what is probably the last (or youngest) group of artists whose work was directly influenced by Rembrandt through an intermediary, like Bol, who worked in his studio.

\section{Acknowledgements}

I thank the staff of the Rijksprentenkabinet for granting me access to drawings by Ferdinand Bol during many visits over a period of years. I also thank Eva Michel of the Albertina for providing me with the opportunity to examine a selection of drawings by Rembrandt and his pupils in February of this year.

Jan L. Leja, an independent art historian, is the author of Ferdinand Bol and Rembrandt: Authorship and Iconography in Drawings of Biblical Subjects, c. 1636-c. 1650 (PhD diss., New York University, Institute of Fine Arts, 2004). She has worked as curator of paintings for a private New York collection and taught undergraduates at New York University. She is currently working on a study of the relationship between word and image in Bol's paintings and drawings.

\section{List of Illustrations}

Fig. 1 Ferdinand Bol, Abraham Meeting the Lord and Two Angels, 1646 or later, pen and brown ink, white body color, 14.5 x $15.9 \mathrm{~cm}$. Rijksmuseum, Rijksprentenkabinet, Amsterdam, inv. no. RP-T-1930-1 (artwork in the public domain)

Fig. 2 Ferdinand Bol (workshop/follower), Abraham Meeting the Lord and Two Angels, after 1646, pen and brown ink, brown and gray wash, 17.6 x $20.3 \mathrm{~cm}$. Graphische Sammlung Albertina, Vienna, inv. no. 8764 (artwork in the public domain)

Fig. 3 Ferdinand Bol, Annunciation, ca. 1636-40, pen and brown ink, brush and brown wash, 19.4 x $16.5 \mathrm{~cm}$. Nasjonalmuseet for kunst, arkitektur og design, Oslo, inv. no. NG.K\&H.B.15591 (artwork in the public domain) 
Fig. 4 Ferdinand Bol, The Angel Appearing to Hagar in the Desert, ca. 1636-40, pen and brown and gray ink, gray wash, $29.3 \times 18.5 \mathrm{~cm}$. Lugt Collection, Paris, inv. no. 2529 (artwork in the public domain)

Fig.5 Ferdinand Bol, Agony in the Garden, ca. 1645, pen and brown ink, touched with red chalk, brown, gray, and yellow wash. The British Museum, London, inv. no. 1918,0615.9 (artwork in the public domain)

Fig. 6 Rembrandt, Abraham Entertaining the Three Angels, 1646, oil on panel, $16.1 \times 21.1 \mathrm{~cm}$. Private collection (artwork in the public domain)

Fig. 7 Pieter Lastman, Abraham Entertaining the Angels, 1616, oil on panel, 82 x $126 \mathrm{~cm}$. On loan to Schloss Wilhelmshöhe, Kassel(artwork in the public domain)

Fig. 8 Ferdinand Bol (or workshop), Abraham Entertaining the Three Angels, ca. 1650, oil on canvas, $55.9 \times 73.3 \mathrm{~cm}$. Private collection (artwork in the public domain)

Fig. 9 Ferdinand Bol, Abraham Entertaining the Three Angels, ca. 1660-63, oil on canvas, $404 \mathrm{x}$ $282.5 \mathrm{~cm}$. Rijksmuseum, gift of the Royaards Family, on loan to Noordbrabants Museum, 's-Hertogenbosch, (artwork in the public domain)

Fig. 10 Lucas van Leyden, Abraham and the Three Angels, ca. 1513, engraving, 17.8 x $13.8 \mathrm{~cm}$. Rhode Island School of Design Museum, Gift of Murray S. Danforth, Jr., Providence, inv. no. 50.326 (artwork in the public domain)

Fig. 11 Detail of Ferdinand Bol, Hagar at the Well on the Way to Shur, early-to-mid 1640s, pen and brown ink, brown wash, 18.2 x $23.2 \mathrm{~cm}$. Rijksmuseum, Rijksprentenkabinet, Amsterdam, inv. no. RP-T-1930-27 (artwork in the public domain)

Fig. 12 Detail of fig. 2

Fig. 13 Ferdinand Bol, David Showing Saul the Tip of His Coat, ca. 1636-41, pen and brown ink, brush and brown wash, 20 x $31 \mathrm{~cm}$. The Metropolitan Museum of Art, Guy Wildenstein Gift, New York, inv. no. 2001.123 (artwork in the public domain)

\footnotetext{
${ }^{1}$ The stylistic similarities between the Rijksmuseum sheet and those in Wrockaw and the private American collection were noted by Werner Sumowski, Drawings of the Rembrandt School, ed. and trans. by Walter L. Strauss (New York: Abaris Books, 1979-92), 1:219*, who illustrated the latter two as nos. 98 and 277, $\mathrm{X}$ respectively.

${ }^{2}$ Ingrid Oud, "De tekeningen van Ferdinand Bol: De relatie tussen de stijl en de functie van de
} 
tekeningen," Kunstlicht 13, no. 1 (1992): 3-10.

${ }^{3}$ Jan L. Leja, "Ferdinand Bol and Rembrandt: Authorship and Iconography in Drawings of Biblical Subjects, c. 1636-c. 1650," 2 vols. (PhD diss., New York University, Institute of Fine Arts, 2004).

${ }^{4}$ Holm Bevers, Rembrandt, Die Zeichnungen im Berliner Kupferstichkabinett (Ostfildern: Hatje Cantz, 2006); Holm Bevers et al, Drawings by Rembrandt and His Pupils: Telling the Difference, exh. cat. (Los Angeles: The J. Paul Getty Museum, 2009); Peter Schatborn, Rembrandt and His Circle: Drawings in the Frits Lugt Collection, 2 vols. (Bussum: Thoth Publishers, 2010); Martin Royalton-Kisch, Catalogue of Drawings by Rembrandt and His School in the British Museum, British Museum online catalogue, 2010 (http://www.britishmuseum.org/research/publications/ online_research_catalogues/rembrandt_drawings/drawings_by_rembrandt.aspx; accessed March 5, 2013); and Annemarie Stefes, Niederländische Zeichnungen 1450-1850, 3 vols. (Cologne, Weimar, and Vienna: Böhlau Verlag, 2011).

${ }^{5}$ The entries appear under the following numbers: Bevers et al., Drawings by Rembrandt, 84-85, fig. 8.2 (in color); Schatborn, Lugt Collection, vol. 1, pp. 108-11, no. 34; vol. 2, no. 34 (repr. in color); and Royalton-Kisch, British Museum online catalogue, 2010, Bol 4.

${ }^{6}$ Sumowski, Drawings, vol. 5, nos. 1277-1281, ${ }^{\mathrm{xx}}$ identified Horst as the author of six drawings, one of which, David on His Death Bed (no. 1277) has also been called a preparatory drawing by Bol for his painting of the same subject (National Gallery of Ireland, Dublin). Later, Sumowski, Gemälde der Rembrandt-Schüler (Landau: Edition PVA, 1979-83), vol. 5, under no. 2005, attributed the drawing to Bol. This author, however, has questioned whether the style of the drawing supports the attribution to Bol: Leja, "Ferdinand Bol and Rembrandt,"1:66-67.

${ }^{7}$ This was the title accepted by John C. Van Dyke, The Rembrandt Drawings and Etchings with Critical Reassignments to Pupils and Followers (New York: Charles Scribner's Sons, 1927), 50, 54, when he published them as the work of Bol in 1927.

${ }^{8}$ In the Statenbijbel (1719-20 edition) Abraham was described in Genesis 17:3 (folio 8) as "Doe viel Abram op sijn aengesichte."

${ }^{9}$ In Genesis 18:2 (folio 9) of the Statenbijbel (1719-20 edition) Abraham was described as "[Abram] boogh sich ter aerde."

${ }^{10}$ Michiel Roscam Abbing, “'Abraham onthaalt de Heer en twee enegelen': Opmerkingen over de titel van de Rembrandt-ets B.29," Kroniek van het Rembrandthuis 2 (1993): 28-34. This distinction was later noted by Netty van der Kamp, "Die Genesis: Die Urgeschichte udn die Geschichte der Erzväter," in Im Lichte Rembrandts: Das Alte Testament im Goldenen Zeitalter der niederländischen Kunst, exh. cat. (Münster: Westfälisches Landesmuseum; Amsterdam: Joods Historisch Museum; and Jerusalem: Israel Museum, 1994), 29; and Petra Jeroense and Christian Tümpel, "Abraham Serving the Lord and Two Angels," in Patriarchs, Angels and Prophets: The Old Testament in Netherlandish Printmaking from Lucas van Leyden to Rembrandt, exh. cat. (Amsterdam: Museum het Rembrandthuis, 1996-97), 69-70.

${ }^{11}$ Roscam Abbing, "Abraham onthaalt de Heer en twee engelen,"' 30, where the author acknowledges that it is not known whether Rembrandt owned a copy of the Statenbijbel.

${ }^{12}$ Lastman painted a second version of this theme which is no longer extant but is known through an undated mezzotint by Jan van Somers (1635/55-1699). In the print Sarah is depicted much as she is in the painting; see F. W. H. Hollstein, Dutch and Flemish Engravings, Etchings and Woodcuts, edited by K. G. Boon, complied by Dieuwke de Hoop Scheffer and George S. Keyes (Amsterdam: Van Gendt \& Co., 1949 to present), 27:112, no. 1. 
${ }^{13}$ The authorship of the earlier painting has been questioned and it is sometimes attributed to a Bol pupil. Margriet van Eikema Hommes, Art and Allegiance in the Dutch Golden Age (Amsterdam: Amsterdam University Press, 2012), 105-09, leaves open the question of authorship.

${ }^{14}$ Leja, "Ferdinand Bol and Rembrandt," vol. 1, chapt 3, and pp. 214-16.

${ }^{15}$ Sumowski, Drawings, 1:259.*

${ }^{16}$ The four include two drawings of Jacob’s Dream (Musée des Beaux-Arts et d'Archéologie, Besançon, and Bibliothèque de l'École Nationale Supérieure des Beaux-Arts, Paris); Three Marys at the Tomb (Staatliche Graphische Sammlung, Munich); and Hagar and the Angel on the Way to Shur (Rijksmuseum, Rijksprentenkabinet, Amsterdam).

${ }^{17}$ The latter drawing is illustrated in Seventeenth-Century Dutch Drawings: A Selection from the Maida and George Abrams Collection, exh. cat. by William W. Robinson, with an introduction by Peter Schatborn (Amsterdam: Rijksmuseum, Rijksprentenkabinet; Vienna: Graphische Sammlung Albertina; New York: The Pierpont Morgan Library; and Cambridge: Harvard University The Fogg Art Museum, 1991-92), cat. 45 (repr. in color).

\section{Bibliography}

Bevers, Holm. Rembrandt: Die Zeichnungen im Berliner Kupferstichkabinett. Ostfildern: Hatje Cantz, 2006.

Bevers, Holm, et al. Drawings by Rembrandt and His Pupils: Telling the Difference. Exh. cat. Los Angeles: The J. Paul Getty Museum, 2009.

Hollstein, F. W. H. Dutch and Flemish Etchings, Engravings and Woodcuts. 72 vols. Edited by K. G. Boon, compiled by Dieuwke de Hoop Scheffer and George S. Keyes. Amsterdam: Van Gendt \& Co., 1949 to present.

Jeroense, Petra, and Christian Tümpel. "Abraham Serving the Lord and Two Angels." In Patriarchs, Angels and Prophets: The Old Testament in Netherlandish Printmaking from Lucas van Leyden to Rembrandt. Exh. cat. by Peter van der Coelen with contributions by Christian Tümpel et al. Amsterdam: Museum het Rembrandthuis, 1996-97.

Leja, Jan L. "Ferdinand Bol and Rembrandt: Authorship and Iconography in Drawings of Biblical Subjects, c. 1636-c. 1650." 2 vols. PhD diss. New York University, Institute of Fine Arts, 2004.

Oud, Ingrid. "De tekeningen van Ferdinand Bol: De relatie tussen de stijl en de functie van de tekeningen." Kunstlicht 13, no. 1 (1992): 3-10.

Robinson, William W., with Introduction by Peter Schatborn. Seventeenth-Century Dutch Drawings: A Selection from the Maida and George Abrams Collection. Exh. cat. Amsterdam: Rijksmuseum, Rijksprentenkabinet; Vienna: Graphische Sammlung Albertina; New York: The Pierpont Morgan Library; and Cambridge: Harvard University, The Fogg Art Museum, 1991-92.

Roscam Abbing, Michiel. “'Abraham onthaalt de Heer en twee engelen': Opmerkingen over de titel van de Rembrandt-ets B 29." Kroniek van het Rembrandthuis 2 (1993): 28-34. 
Royalton-Kisch, Martin. Catalogue of Drawings by Rembrandt and His School in the British Museum. British Museum online catalogue, 2009. http://www.britishmuseum.org/research/publications/online_research_catalogues/rembrandt_drawings/drawings_by_rembrandt.aspx. Accessed March 5, 2013.

Schatborn, Peter. Rembrandt and His Circle: Drawings in the Frits Lugt Collection. 2 vols. Bussum: Thoth Publishers, 2010.

Biblia, dat is gantsche H. Schrifture, vervattende alle de canonijcke boecken des Ouden en des Nieuwen Testaments. ... [the so-called Statenbijbel]. Dordrecht: P. Keur, 1719-20. Stefes, Annemarie. Niederländische Zeichnungen 1450-1850. 3 vols. Cologne, Weimar, Vienna: Böhlau Verlag, 2011.

Sumowski, Werner. Gemälde der Rembrandt-Schüler. 6 vols. Landau: Edition PVA, 1979-83.

Sumowski. Werner. Drawings of the Rembrandt School. 10 vols. Edited and translated by Walter L. Strauss. New York: Abaris Books, 1979-92.

Van der Kamp, Netty. "Die Genesis: Die Urgeschichte und die Geschichte der Erzväter." In Im Lichte Rembrandts: Das Alte Testament im Goldenen Zeitalter der niederländischen Kunst. Exh. cat. by Christian Tümpel et al. Münster: Westfälisches Landesmuseum; Amsterdam: Joods Historisch Museum; and Jerusalem: Israel Museum, 1994.

Van Dyke, John C. The Rembrandt Drawings and Etchings with Critical Reassignments to Pupils and Followers. New York: Charles Scribner's Sons, 1927.

Van Eikema Hommes, Margriet. Art and Allegiance in the Dutch Golden Age. Amsterdam: Amsterdam University Press, 2012.

Recommended Citation:

Jan Leja, "Abraham Meeting the Lord and Two Angels: Making the Case for Ferdinand Bol and Workshop," JHNA 5:2 (Summer 2013), DOI: 10.5092/jhna.2013.5.2.13 